\title{
Nilai Sosial dan Makna Pemertahanan Bahasa Melayu Dialek Sambas melalui Lagu Daerah dalam Album Terigas
}

\author{
Muchammad Djarot \\ Institut Agama Islam Negeri Pontianak : muhammad_djarot@yahoo.com
}

\begin{tabular}{l}
\multicolumn{1}{c}{ Artikel Info } \\
\hline \\
Kata Kunci: Makna, \\
Bahasa, Dialek, Nilai \\
Sosial, Melayu
\end{tabular}

\begin{abstract}
Abstrak
Album Terigas merupakan kumpulan lagu daerah berbahasa Melayu yang sanggup merepresentasikan nilai sosial dan proses pemertahanan bahasa daerah. Dengan aransemen yang tepat, lagu-lagu daerah dalam Album Terigas tidak sekadar dinyanyikan dalam upacara adat, melainkan juga dalam kegiatan seharihari. Tulisan ini mengidentifikasi nilai-nilai sosial yang terkandung dalam lagu daerah dan identifikasi makna pemertahanan bahasa Melayu Dialek Sambas (BMDS) melalui lagu daerah di Album Terigas. Tujuan dari tulisan ini adalah untuk mendeskripsikan nilai-nilai sosial yang terdapat dalam lagu daerah dan makna pemertahanan BMDS melalui lagu daerah. Metode yang digunakan dalam penelitian ini adalah deskriptif dengan bentuk penelitian kualitatif dengan penekanan pada penguraian kondisi objek penelitian yang berupa lirik lagu. Hasil dari penelitian menyatakan bahwa dalam lirik lagu daerah Sambas dalam Album Terigas terdapat nilai religius, nilai etos kerja dan kerjasama, serta nilai sejarah dan budaya. Selain nilai sosial, terdapat juga makna pemertahanan bahasa melalui lagu daerah di antaranya penyadaran identitas kesukuan, pelestarian BMDS sebagai bahasa daerah, pembentuk sikap dan perilaku hidup bermasyarakat.
\end{abstract}

\section{A. PENDAHULUAN}

Isu globalisasi yang merupakan ciri abad 21 terdengar semakin intensif. Segala hal menjadi global, mulai dari ekonomi, politik, sosial, hingga kebudayaan. Fenomena globalisasi adalah kabar baik. Batas-batas antarnegara diruntuhkan dengan semakin mudahnya akses informasi dan transportasi, perkembangan semakin massif hingga memunculkan banyaknya metropolitan baru, pakar sains dan teknologi berinovasi tanpa henti menciptakan perangkat yang memudahkan kehidupan manusia, sistem ekonomi saling terkait: keadaan ekonomi di satu negara bisa memengaruhi negara lainnya. Selain itu, yang paling besar dampaknya adalah terjadinya interaksi antarmasyarakat. Interaksi tersebut menyebabkan terjadinya pertukaran dan transfer kebudayaan. Dengan demikian akan terjadi perubahan, walau tidak signifikan dalam waktu singkat, pada komponen-komponennya. Satu di antaranya yang ikut terpengaruh adalah komponen bahasa.

Interaksi antarmasyarakat pengguna bahasa adalah yang lazim. Sebelum globalisasi mencuat pada abad 21, interaksi ini lah yang mengakibatkan terjadinya perubahan bahasa-bahasa di nusantara. Perubahan yang dimaksud dikategorikan ke dalam dua hal, pertama adalah perubahan ke arah positif dan bersifat membangun. Kedua adalah dampak negatif yang bersifat merusak bahasa dan penuturnya. Bertambahnya kosakata, semakin mudahnya menamai sesuatu, hingga sebagai alat transfer pengetahuan adalah perubahan positif yang diakibatkan oleh interaksi antarmasyarakat pengguna bahasa yang berbeda. Terjadinya seleksi bahasa, penghilangan, hingga munculnya anggapan bahwa bahasa ibu bernilai lebih rendah daripada bahasa lain adalah beberapa perubahan negatif. 
Sebagai alat transfer kebudayaan dan sebagai komponen dari kebudayaan, bahasa, terutama bahasa ibu perlu mendapatkan perhatian serius. Hal ini terutama menyangkut perubahan-perubahan negatif akibat interaksi yang telah dipaparkan. Dalam pada itu bahasa pertama yang di kuasai manusia sejak awal hidupnya melalui interaksi dengan sesama anggota masyarakat bahasanya atau yang sring disebut dengan konsep bahasa ibu (native language atau mother language) yang diperoleh sacara intuitif (Kridalaksana, 1993:22-23). Dengan demikian, maka dalam pemerolehan kebudayaan setempat oleh seorang anak manusia yang menjadi anggota masyarakat di tempat itu berlangsung pula secara intuitif dan simultan tatkala mereka mereka mempelajari bahasa ibunya.

Fungsi utama Bahasa ibu adalah sebagai alat komunikasi (Chaer dan Agustin (1995:14). Hal ini sejalan dengan Soeparno (1993:5) yang menyatakan bahwa fungsi umum bahasa adalah sebagai alat komunikasi sosial. Sosiolinguistik memandang bahasa sebagai tingkah laku sosial (social behaviour) yang dipakai dalam komunikasi sosial.

Schumann dan Nancy Stenson (1974:3940) mengatakan bahwa:

The functions of language are three components : communicative, integrative and expressive. Through the communicative function information is exchanged among persons. The integrative function serves to mark one's identity within the society and the expressive function is designed to allow the expression of certain psychological needs.

Dari kutipan ini terlintas bahwa fungsi bahasa seperti ini bisa digunakan untuk mendefinisikan konsep bahasa ibu tersebut. Uraian berikut dengan data empiris akan memberikan hasil yang bisa lebih memadai.

Konsep bahasa ibu atau bahasa pertama masih menjadi polemik kalau kita mengacu pada situasi masyarakat tutur yang dwibahasawan, seperti masyarakat yang sejak lahir hidup di perkotaan. Pada masyarakat eka bahasawan, seperti di Inggris akan tetap mengatakan bahwa bahasa ibu / pertamanya adalah bahasa Inggris (Platt, 1985). Pada masyarakat ekabahasawan, pemerolehan bahasa ibu memiliki stages, method dan function.

Diawali dengan kemampuan masyarakat menggunakan lebih dari satu bahasa dan berujung pada seleksi bahasa, kemungkinan tersingkirnya bahasa lokal dari penggunaan oleh penuturnya akan semakin besar. Ketika masyarakat sudah mengenal bahasa lain, selain dari bahasa ibunya, dan berada dalam lingkungan yang jamak serta didukung oleh kebijakan politis untuk melakukan seleksi bahasa, bahasa ibu yang pada saat semula merupakan bahasa asli perlahan akan dilupakan. Hal ini dengan mudah diamati pada penggunaan diksi penutur bahasa. Kosakata asli akan digantikan oleh kosakata lainnya yang bisa dipahami oleh penutur bahasa lain. Pada tahap ini, penggantian (seleksi, pemilihan) masih berada dalam tahap yang wajar.

Namun akan mendatangkan masalah jika fenomena tersebut berlanjut ke dalam komunitas penutur asli. Beberapa contohnya yang bisa ditemukan dalam bahasa Melayu Sambas adalah sebagai berikut: kata sud $\bar{b}$ ? digantikan oleh sendok, kata capal digantikan oleh sandal, kata selawar digantikan oleh celane, kata ap Jan digantikan oleh panci, kata tipkap digantikan oleh jendele, kata sondok digantikan oleh kunci.

Beberapa kata di atas adalah sebagai contoh terjadinya seleksi bahasa. Hal itu jika terjadi terus menerus akan membahayakan bahasa ibu. Semakin lama penutur bahasa Melayu Sambas cenderung menggunakan bahasa yang berafiliasi ke sistem bahasa Indonesia walaupun dengan penyesuaian di beberapa bagian: khususnya dalam bagian fonologi dengan mengganti fonem $a$ menjadi fonem $e$. Perubahan bahasa atau 
pergeseran pola berbahasa terjadi secara lambat dan dalam waktu yang sangat panjang. Pergeserannya tidak serta merta teramati. Perubahan bahasa, teramati pada hilangnya bunyi pada satuan lingual, perubahan struktur fonem dalam satu kata atau struktur split. Perubahan dalam tubuh bahasa disebut perubahan internal. Selain perubahan internal, terdapat juga perubahan eksternal. Perubahan jenis ini diakibatkan oleh masuknya unsur-unsur bahasa lain ke tubuh bahasa tersebut. Misalnya, peminjaman kosakata dari bahasa lain untuk memenuhi kebutuhan bahasa tersebut. Berdasar pemaparan tersebut dapat dipahami bahwa ranah fonologi, morfologi, sintaksis, dan semantik akan mengalami perubahan secara perlahan.

Nilai sosial adalah nilai yang dianut oleh suatu masyarakat mengenai apa yang dianggap baik dan apa yang dianggap buruk oleh masyarakat. Sebagai contoh, orang menganggap menolong memiliki nilai baik, sedangkan mencuri bernilai buruk. Nilai sosial merupakan petunjuk umum yang telah berlangsung lama, yang mengarahkan tingkah laku dan kepuasan dalam kehidupan sehari-hari.

Untuk melihat nilai sosial yang ada dalam sastra kita bisa melacaknya melalui kristal-kristal nilai yang berupa: tradisi, konvensi dan norma masyarakat yang ada dalam sastra. Seperti dikatakan oleh Wellek dan Warren (1989:109) bahwa sastra sebagai institusi sosial yang memakai medium bahasa, dalam menyampaikan pesan disalurkan dalam bentuk simbolisme yang berupa konvensi dan norma sosial. Biasanya simbolisme itu berkaitan dengan situasi sosial tertentu, politik, ekonomi dan sebagainya.

Holmes (1993:14) mengatakan tiga faktor utama keberhasilan pemertahanan bahasa:

1. Jumlah orang yang mengakui bahasa tersebut sebagai bahasa ibu mereka. Dilihat dari kuantitas, jumlah penutur yang banyak pada sebuah bahasa membuat sebuah bahasa dapat bertahan.

2. Jumlah media yang mendukung bahasa tersebut dalam masyarakat (sekolah, publikasi, radio). Jika media massa seperti radio, televisi, koran, buku-buku sastra menggunakan bahasa daerah maka akan mendukung pemertahanan sebuah bahasa.

3. Indeks yang berhubungan dengan jumlah orang yang mengakui dengan perbandingan total dari media media pendukung.

4. Jumlah atau kuantitas penutur yang banyak dan media-media pendukung pemakaian sebuah bahasa sangat berpengaruh terhadap pemertahanan sebuah bahasa.

Pemertahanan bahasa sebagaimana yang ditunjukkan hasil kajian yang dilakukan para pakar pemeliharaan bahasa merupakan usaha agar suatu bahasa tetap dipakai dan dihargai terutama sebagi identitas suatu kelompok dalam masyarakat bahasa yang bersangkutan (Kridalaksana, 2001:159). Jendra (2012:26) menyatakan pemertahanan bahasa adalah situasi ketika sebuah komunitas dapat mempertahankan atau melanjutkan penggunaan bahasa mereka dari generasi ke generasi meskipai saranaun ada kondisi yang dapat mempengaruhi mereka untuk beralih ke bahasa lain.

Dalam penelitian yang dilakukan Mardikantoro (2016), pemertahanan bahasa dapat dilakukan melalui kesenian tradisional. Kesenian tradisional memiliki potensi besar sebagai sarana pemertahanan bahasa. Hal ini disebabkan karena kesenian tradisional masih menggunakan bahasa daerah sebagai sarana pertunjukan. Bahasa daerah digunakan dalam mantra, penamaan unsur budaya, istilah dalam budaya, dan lain sebagainya. Oleh sebab itu upaya pemertahanan bahasa daerah dapat dilakukan melalui kesenian tradisional. 
Melalui sikap positif masyarakat bahasa untuk mempertahankan bahasanya akan mencegah pergeseran bahasa yang mengarah pada kepunahan bahasa. Sebaliknya tanpa kesadaran suatu masyarakat untuk memelihara atau melestraikan bahasanya, maka akan mempercepat kepunahan bahasa sebagaimana.

Berdasarkan latar belakang tersebut, penulis tertarik untuk meneliti tentang nilainilai sosial yang terkandung dalam lagu daerah Sambas dan pemertahanan Bahasa Melayu Dialek Sambas (BMDS) melalui lagu daerah. Penulisan ini menekankan pada banyaknya pesan yang disampaikan oleh nenek moyang terdahulu melalui lagu daerah sebagai bekal anak cucunya kelak di masa yang akan datang. Beberapa nilai yang terdapat dalam lirik Album Terigas tersebut yaitu nilai religius, nilai etos kerja dan kerjasama, nilai sejarah dan budaya tentang masyarakat Melayu yang ada di Kabupaten Sambas Provinsi Kalimantan Barat. Seiring berkembangnya zaman lagu daerah mulai ditinggalkan karena dianggap tidak sesuai dengan zaman sekarang dan dianggap kuno dikarenakan generasi milenial sekarang lebih menyukai bahasa gaul. Oleh karena itu selain nilai sosial yang terkandung dalam lagu daerah Melayu Sambas, peneliti juga menyoroti tentang masalah pemertahanan bahasa daerah melalui lagu daerah agar kelak BMDS tidak hilang ditelan zaman.

\section{B. METODE}

Perlu dilakukan suatu upaya agar bahasa ibu tetap digunakan di masyarakat: beserta sistemnya dalam bentuk dan komposisi yang asli. Upaya itu lazim dinamai dengan pemertahanan bahasa. Sebagai usaha agar bahasa setempat tidak terkikis oleh peristiwa pergeseran bahasa atau proses multilingual, maka pemertahanan bahasa perlu dilakukan. Namun bisa saja bahasa pertama tetap dapat bertahan terhadap pengaruh penggunaan bahasa kedua apabila penutur bahasa pertama konsisten dan mempertahankan keberadaannya. Upaya untuk mempertahankan bahasa bukanlah perkara mudah. Apalagi didukung oleh mobilitas penutur yang tinggi sehingga menyebabkan terjadinya interaksi yang intensif, menjadikan hal tersebut perlu mendapatkan perhatian serius.

Pelbagai upaya dilakukan dalam upaya pemertahanan bahasa. Studi yang intensif dan berkelanjutan adalah satu di antaranya. Berkaitan dengan hal ini, Wijana (2012:89) mengungkapkan:

Pemeliharaan bahasa tidak cukup hanya dengan usaha mendeskripsikan sistem kebahasaan dan wilayah pemakainya, seperti yang dilakukan oleh pemakai bahasa selama ini. Namun yang tidak kalah penting adalah penumbuhan rasa bangga dalam diri penutur untuk menggunakan bahasanya. Kebanggaan berbahasa (linguistic pride) di samping kesadaran terhadap norma (awareness of norm) merupakan faktor yang amat penting bagi keberhasilan usaha pemertahanan bahasa. Kebanggaan linguistik dapat dibangkitkan dari kekhasan-kekhasan yang dimiliki oleh bahasa itu.

Berdasar pendapat yang telah dikemukakan oleh Wijana, rasa bangga diwujudkan dalam penggunaan bahasa (termasuk ragam bahasa) dalam kehidupan sehari-hari. Satu di antara bentuknya adalah dengan lagu daerah: menyanyikannya dalam pelbagai acara masyarakat.

Metode yang digunakan dalam penulisan ini berbentuk deskriptif dengan pendekatan kualitatif. Bentuk ini dipilih untuk menguraikan data yang berupa liriklirik lagu sehingga bisa mengungkapkan nilai-nilai sosial dan makna pemertahanan bahasa yang dikandungnya. Nawawi (1996: 63) menyatakan bahwa metode penelitian deskriptif dapat diartikan sebagai prosedur pemecahan masalah yang diselidiki dengan menggambarkan atau melukiskan keadaan 
subjek/objek penelitian (seseorang, lembaga, masyarakat, dan lain-lain) pada saat sekarang berdasarkan fakta-fakta yang tampak dan sebagaimana mestinya. Metode deskriptif ini digunakan untuk menggambarkan apa adanya hasil dari pengumpulan data yang telah dilakukan oleh penulis.

Data primer dalam penelitian ini adalah lirik lagu daerah dan data sekunder berupa dokumen terkait penelitian yaitu buku, dan dokumen lain. Data dalam penelitian ini di ambil dari kata-kata yang berkenaan dengan kumpulan lagu daerah yaitu Album Terigas Sambas. Teknik pengumpulan data yang digunakan dalam penelitian ini adalah teknik studi dokumenter sebab peneliti mengumpulkan data melalui bahan-bahan tertulis yakni lirik lagu daerah dalam Album Terigas. Prosedur dan teknik analisis data berupa penerjemahan, identifikasi dan klarifikasi, analisis data, penafsiran dan penarikan kesimpulan.

\section{HASIL DAN PEMBAHASAN}

\section{Nilai-Nilai Sosial pada Lagu Daerah Sambas}

Upaya pemertahanan bahasa mesti didasari oleh hal-hal yang substantif. Dengan demikian upaya yang dilakukan akan memiliki manfaat dan berpotensi meningkatkan prestise sebuah bahasa di kalangan penuturnya. Satu di antara hal substantif yang dimiliki oleh sebuah bahasa, yang dalam ini tergambar melalui lagu daerah adalah nilai-nilai sosial yang dikandungnya. Dengan mengacu pada pemikiran umum bahwa suatu hasil kebudayaan merupakan refleksi dan citacita luhur sekelompok masyarakat, maka nilai-nilai sosial yang ada di dalam lagu perlu diuraikan untuk mendukung upaya pemertahanan bahasa tersebut.

Nilai sosial bukan sekadar takaran baik dan buruknya suatu perbuatan dalam pandangan masyarakat. Ianya mencakup bentuk penghormatan terhadap segala hal yang dianggap penting, luhur, dan memiliki manfaat bagi masyarakat. Nilai sosial memiliki autoritas untuk mengarahkan perilaku anggota masyarakat agar tertib dan memenuhi kepuasan bersama. Dengan demikian nilai sosial akan selalu dijunjung tinggi dan dipelihara agar tercapai tujuantujuan yang telah ditetapkan. Nilai sosial memiliki peran nyata dalam kehidupan masyarakat. Membentuk stratifikasi sosial, pendorong agar tiap individu berbuat baik, memberi semangat, hingga menjadi alat penguat solidaritas agar masyarakat saling bekerja sama dalam mencapai cita-citanya.

Berkaitan dengan hal yang telah dipaparkan, lagu daerah yang telah bertahan antargenerasi dalam waktu yang cukup panjang dianggap memiliki atau mengandung nilai-nilai tersebut. Pemeliharaan lagu menunjukkan bahwa ada satu hal yang penting yang terkandung di dalamnya dan hal ini akan berimbas pada pemertahanan bahasa. Dengan kata lain, pemelihaaraan lagu daerah yang diakibatkan oleh nilai-nilai sosial yang dimilikinya dan pemertahanan bahasa yang digunakan dalam lagu daerah adalah dua hal yang berjalan beriringan.

Adapun beberapa nilai sosial yang terungkap dalam lagu-lagu daerah Sambas dipaparkan sebagai berikut.

1. Nilai Religus dalam lagu daerah Tandak Sambas dan Passan Nek Along

Sebagai sebuah daerah yang didominasi oleh penduduk yang beragama Islam, masyarakat Kabupaten Sambas meletakkan nilai religius pada urutan yang pertama. Nilai religius ini tidak sekadar menjadi sesuatu yang melekat di luar, namun telah terinternalisasi ke dalam setiap aktivitas masyarakat. Setiap perkara selalu dikaitkan dengan nilai-nilai religi. Bahkan dalam setiap acara adat pun, sisi-sisi keagamaan selalu tampak melalui pembacaan bismillah atau pun pembacaan selawat kepada Nabi Muhammad Saw. Nilai religius ini juga membentuk norma tak tertulis di 
masyarakat. Sebagai sebuah contoh, bagaimana seharusnya pergaulan antara laki-laki dengan perempuan dan bagaimana sikap seorang Melayu dalam menjalankan kewajiban beragamanya. Nilai religius ini tampak pada bait lagu berjudul Tandak Sambas berikut,

Duak lah beduak, duak beduak bujang betandak

Langkah, langkah dilangkah marilah kite besamelah same

Tandaklah sambas sunggoh gembire Ngiborkan ati gundah gulane

Baris pertama dalam lagu Tandak Sambas mengisyaratkan bahwa dalam berseni pun, ada aturan pergaulan antara laki-laki dan perempuan. Berdasar lagu tersebut pada hakikatnya laki-laki dan perempuan tidak diperkenankan bersentuhan dan berada dalam satu arena atau satu persembahan tarian. Tentu saja aturan ini merupakan nilai religius yang diambil dari agama Islam: agama yang sekaligus menjadi pedoman dan pembentuk pola hidup masyarakat Sambas. Selanjutnya nilai religius tampak pada bait berikut,

Maseh ingat ke kawan? Uddah luppak

Passan jannat Nek Along. Passan ape?

Belajar lah ngaji, sampaikan ke hattam, ussah luppak sembahyang

Lagu berjudul Passan Nek Along tersebut mengisahkan tentang nasihat yang diberikan oleh orang tua kepada anak cucunya. Belajar mengaji sampai selesai dan tidak lupa beribadah (masyarakat Melayu cenderung menggunakan istilah sembahyang dibandingkan sholat) adalah pesan utama dalam lagu tersebut. Perlu dipahami bersama bahwa walaupun pelajaran Agama Islam diajarkan di sekolah, sebagian besar masyarakat Melayu mendapatkan pendidikan agama melalui jalur nonformal. Pak Labbai, Pak Aji, dan guru ngaji adalah aktor utama dalam mengejawantahkan hal tersebut. Ketiganya berperan besar dalam banyak hal, terutama ketika mengajari masyarakat belajar membaca Alquran dan menjadi imam sholat.

Nilai religius yang terdapat di dalam lagu adalah hal yang sangat menarik. Dengan demikian si penutur bahasa akan mendapatkan banyak hal ketika mereka akrab dengan lagu daerah. Dengan sikap positif terhadap lagu, masyarakat Melayu akan membiasakan diri tetap berbahasa Melayu sekaligus memeroleh nilai-nilai religius yang terdapat di dalamnya.

\section{Nilai Etos Kerja dan Kerja Sama dalam Lagu Belallek, Simberapian, TKI, dan Senandong Perantau}

Sambas merupakan wilayah agraris yang sebagian besar penduduknya bekerja sebagai petani. Dengan menerapkan sistem tadah hujan, hasil panen sepenuhnya bergantung pada musim. Drainase persawahan tidak dimanajemen dengan baik sehingga beberapa tahun terakhir kerap kali terjadi gagal panen di beberapa kecamatan. Beraktivitas sebagai petani membentuk suatu pola hidup yang unik bagi masyarakat Melayu. Pasalnya banyak sekali aktivitas itu yang mengharuskan mereka hidup secara komunal dan melakukannya secara bersama. Bukan berarti masyarakat Melayu tidak mampu berdikari, namun sistem sosial yang disepakati adalah demikian adanya. Hal ini tampak pada lagu Belallek yang berbunyi,

Belallek, kite belallek besame-same.

Dah kawan kawan kite belallek, padi dah masak di barang inun

Sodahnak lupak bawak alatnye, kite belallek besame-same

Belallek dalam bahasa Melayu Dialek Sambas berarti'bekerja sama' adalah hal yang lazim dilakukan. Aktivitas yang tergambar di dalam lagu tersebut adalah ketika hendak memanen padi. Walau pada saat ini sudah ada mesin untuk memanen, masih ada sebagian masyarakat yang memanen padi secara manual menggunakan kattam 'ani-ani'. Waktu yang dibutuhkan untuk memanen sepetak sawah jika menggunakan kattam tidak sebentar, oleh 
sebab itu masyarakat Belallek dari satu sawah ke sawah lainnya secara bergantian. Selanjutnya pada lirik lagu Simberapian

Simberapian, kite simberapian

Lakaslah oi ke kampong Angus, ke rumah Long Pira,

Simberapian, kite simberapian

Ulamnye daun simpor lippit, kerabu keladi

Singgah dolok ke lanting Pak Ammok

Mballi tamban, paddak, incalok

Sukke inyan kamek ari itok

Simberapian di rumah Long Pira

Lirik Simberapian menggambarkan suasana yang akrab di masyarakat. Masak dan makan bersama adalah hal yang lumrah dilakukan dan bertujuan untuk meningkatkan solidaritas antaranggota masyarakat. Beberapa lagu yang telah dikemukakan di atas secara tersirat menunjukkan bahwa masyarakat Sambas hidup dengan bertani. Namun tidak seluruhnya demikian, sebagian masyarakat Sambas memilih untuk merantau: bekerja sebagai TKI atau bekerja di perusahaanperusahaan di luar daerah. Hal ini tergambar dari lirik lagu TKI

Tebayang bayang rummah di kampong, teringat kabbon gattah ngan kopi

Ore ramainye anak dare ke umme, kampong yang dak dapat kulupakkan

Bile kamek barok sampat mantau, salok inyan rase nak bemalam

Sukenye mun mussem buah buahan, mun musem rambutan suke inyan

Bagaimane kini keadaan kampong, maklom lah lamak pagi merantau

Incarek rijakki nambah pengalaman, jadi TKI di Malaysia

Selanjutnya dalam lirik Senandong Perantau

Sembelan bullan udah belalu aku ninggalkan mak ngan adekku

Ape kabarnye ape cerite mudah mudahan dissek alangan

Slamak ayah udah ndak ade terase susah nak ngape ngape
Aku tipakse ninggalkan kampong mudah-mudahan nasibku untong

Aku merantau jaoh di mate bukan singaje nak nyarek suke

Aku ninggalkan kampong halaman satu tujuan tok mase dappan

Lagu Senandong Perantau menggambarkan suatu keadaan ketika masyarakat lebih memilih keluar daerah untuk mencari kehidupan yang lebih baik. Lirik lagu daerah yang dikemukakan menunjukkan bahwa ada nilai etos kerja dan kerja sama yang dijunjung tinggi oleh masyarakat Melayu.

\section{Nilai Sejarah dan Budaya dalam Lagu Punji Kate, Batu Mak Jage}

Sambas bukan saja sebuah kabupaten yang berdiri secara administratif. Pada mulanya ia merupakan sebuah kerajaan Hindu yang berada dalam naungan kekuasaan Majapahit. Sejak Majapahit runtuh, Sambas dipimpin oleh raja-raja Melayu yang beragama Islam dan mencapai puncak kejayaannya di bawah pimpinan Sultan Muhammad Tsafiuddin. Perpaduan Hindu dan Islam pada masa lampau menciptakan suasana kultural yang unik dalam masyarakat Melayu. Keunikan ini tampak pada lagu-lagu yang bertemakan legenda, sejarah, hingga kepercayaan terhadap benda-benda alam.

Kepercayaan terhadap animisme dan dinamisme tidak sepenuhnya dihilangkan walau sebagian besar masyarakat Melayu telah beragama Islam. Hal ini ditunjukkan oleh banyaknya mantra-mantra yang tersebar di masyarakat dan hingga saat ini masih digunakan dan tetap terpelihara. Bahkan ada sebuah lagu yang berisi mantra. Punji Kate adalah judul lagu tersebut.

Asap kemayyan di tarrang bullan kelambu kunning ikat ke langngan Barkatlah kite memakai kate punji disape jadi saudare

Mayang digantar, kate diumbar, seganggam ratteh tabbar ditabbar 
Krus simangat si dare besimpol jiwe menyatu rase

Punji Kate adalah lagu yang mengandung mantra pengasih, dibacakan untuk memikat lawan jenis. Berdasar lagu tersebut, dapat diketahui bahwa masyarakat Melayu masih sering melakukan aktivitas supranatural dengan melibatkan mantramantra dan sesaji. Walaupun zaman sudah semakin modern, mantra dan sesaji adalah hal yang begitu akrab bagi masyarakat Melayu Sambas. Penggunaan daun juang, kelapa, sirih-pinang, beras, dan sebagainya yang diletakkan di dalam nampan kemudian dilsimpan di pojok rumah untuk menyertai acara-acara adalah hal yang biasa.

Lagu daerah tidak sekadar mengungkapkan kepercayaan terhadap hal gaib dalam kehidupan masyarakat, ianya juga mengungkapkan sejarah beserta legenda yang menyertainya. Sebagian sejarah atau pun legenda merupakan suatu hal yang umum bagi semua masyarakat Melayu di nusantara, misalnya legenda Batu Ballah. Namun masyarakat Melayu Sambas juga memiliki hal-hal lain yang memberikannya ciri. Hal ini terdapat pada lagu Batu Mak Jage dan Bantellan. Berikut adalah petikan lirik lagu Batu Mak Jage

Kayoh kayoh kayoh ke ulu Batu Makjage

Ade satu cerite sungai ulu aeknye darras

Ramai urang injale apebile di mussem landas

Kesah Mak Jage ngael ade batu dakkat kaelnye

Pelanjau name kampongnye sampai itok maseh buktinye

Batu Mak Jage adalah sebutan untuk batu yang ada di tengah sungai dan akan tampak ketika airnya surut. Ianya terletak di Kampung Pelanjau, Kecamatan Tebas. Ada satu hal yang menarik dalam lagu ini, yakni kemampuannya menunjukkan hubungan yang baik antarsuku yang tinggal di Sambas. Pelanjau adalah sebuah kampung yang didiami oleh masyarakat Dayak. Tidak sekadar tinggal, masyarakat Dayak pun telah membangun rumah panjang dan beberapa tempat pemujaan. Munculnya lagu Batu Makjage yang berbahasa melayu sedangkan objeknya berada di pemukiman Dayak menunjukkan adanya interaksi yang baik antara suku Melayu dan Dayak.

\section{Makna Pemertahanan Bahasa Melayu Dialek Sambas (BMDS) melalui Lagu Daerah}

Terungkapnya nilai-nilai sosial dalam lagu daerah menunjukkan bahwa lagu daerah memiliki sesuatu yang patut dilestarikan. Pelestarian ini pun berkorelasi positif terhadap pemertahanan BMDS. Selain nilai sosial, pada bagian ini akan diuraikan pelbagai makna pemertahanan bahasa melalui lagu daerah.

\section{Penyadaran Identitas Kesukuan}

Identitas kesukuan kerap kali disalahartikan dengan primordialisme, suatu pandangan yang menganggap rendah kelompok lain. Hal ini diakibatkan oleh tindakan anarkis yang dilakukan oleh sebagian oknum. Primordialisme ini bisa berujung pada pertikaian antarkelompok. Hal inilah yang harus dihindarkan. Penyadaran identitas kesukuan pada hakikatnya adalah sebuah upaya agar masyarakat tetap berada dalam jalur yang dicita-citakan. Penyadaran identitas kesukuan bisa diwujudkan dalam pelbagai bentuk. Bentuk yang mampu bertahan dan ditransmisikan antargenerasi satu diantaranya adalah lagu daerah. Ianya selalu dinyanyikan dan memiliki kemampuan untuk merepresentasikan kehidupan masyarakat dengan sangat baik.

\section{Pelestarian BMDS sebagai Bahasa Daerah}

BMDS tidak saja digunakan oleh masyarakat Melayu, selain itu juga digunakan sebagai bahasa pengantar dalam masyarakat multikultur khususnya di Kabupaten Sambas Kalimantan Barat. Maksudnya adalah BMDS juga digunakan oleh masyarakat non-Melayu ketika berinteraksi dengan suku-suku lainnya. 
Melestarikan lagu-lagu daerah tentu akan berdampak pada pemertahanan bahasa. Untuk memahami makna yang terdapat di dalam lagu dibutuhkan kemampuan berbahasa yang mendalam. Dengan demikian pemaknaan dan pelestarian lagu daerah akan mendorong masyarakat untuk terus menggunakan bahasa daerah.

\section{Pembentuk Sikap dan Perilaku Hidup Bermasyarakat}

Lagu daerah, berdasarkan pemaparan yang telah diberikan, tidak sekadar bernilai estetika (hiburan). Lebih daripada itu, juga mampu memberi panduan bagi masyarakat untuk bersikap. Lagu daerah mengandung banyak sekali nasihat, pandangan hidup, dan perkaraperkara lain yang bermanfaat bagi kehidupan masyarakat. Lagu daerah juga memiliki nilai-nilai sosial yang bisa diterapkan dalam kehidupan sehari-hari. Nilai sosial tersebut merupakan cita-cita bersama yang direfleksikan dalam sebuah lagu yang indah.

\section{SIMPULAN}

Lagu daerah adalah satu komponen kebudayaan yang masih dilestarikan hingga saat ini. Selain memiliki sifat estetis, lagu daerah juga mengandung nilai-nilai sosial yang selalu dijunjung dan dijadikan cita-cita bersama sekelompok masyarakat. Pelestarian lagu daerah akan berdampak positif terhadap upaya pemertahanan Bahasa Melayu Dialek Sambas. Semakin intensif pelestarian dan pengkajian terhadap lagu daerah, semakin intensif pula upaya pemertahanan bahasa.

\section{DAFTAR PUSTAKA}

Agustin Leonie dan Chaer Abdul. (1995). Sosiolinguistik Perkenalan Awal. Jakarta: PT Rineka Cipta.

Effendy, Chairil. (2006). Sastra sebagai Wadah Integrasi Budaya. Pontianak: STAIN Pontianak Press.
Holmes. (1993). Language Maintenance and Shit in Three New Zealand Speech Community.

Jendra, Made Iwan Indrawan. (2012). Sosiolinguistics The Study Of Societies Language. Yogyakarta: Graha Ilmu.

Kridalaksana, Harimurti (Ed). (1986). Pengembangan Ilmu Bahasa dan Pembinaan Bahasa. Flores. Nusa Indah.

Kridalaksana, Harimurti (Ed). (1993). Kamus Linguistik. Jakarta: PT Gramedia.

Mardikantoro, Hari Bakti. (2016). "Bentuk Pergeseran Bahasa Jawa Masyarakat Samin dalam Ranah Keluarga". Jurnal Litera.Vol.11 No.2 Hlm.204215.

Merti, Ni Made. (2010). "Pemertahanan Bahasa Bali dalam Masyarakat Multikultural di Kota Denpasar. (Tesis). Universitas Udayana Denpasar.

Muhammad. (2011). Metode Penelitian Bahasa. Yogyakarta: Arruzz Media.

Nawawi, Hadari. (1992). Instrumen Penelitian Bidang Sosial. Yogyakarta. Gadjah Mada University Press.

Nurhayati, Endang. "Model Pemertahanan Bahasa Jawa Provinsi Daerah Istimewa Yogyakarta”. Artikel Ilmiah Program Studi Pendidikan Bahasa Daerah Universitas Negeri Yogyakarta.

Platt. John T., Heidi Weber dan Ho. (1985). New Englishes. Singapore: Kegen \& Routledge

Siregar, Bahren Umar, D. Syahrial Isa, \& Chairul Husni. (1998). Pemertahanan Bahasa dan Sikap Bahasa: Kasus Masyarakat Bilingual di Medan. Jakarta: Pusat Pembinaan dan Pengembangan Bahasa Departemen Pendidikan dan Kebudayaan.

Soeparno. (1993). Dasar-dasar Linguistik. Yogyakarta: Mitra Gama Widya. 
Schumann, John dan Nancy Stenson (eds). (1974). New Frontiers in Second Language Learning.

Massachusetts: Newburry House Publishers 